\title{
A Study of Nine Newly Reported Species of the Order Chlorococcales (Chlorophyta) in Hongcheon River, Korea
}

\author{
Hyun-Joo Shin ${ }^{1}$, Mi-Ae Song ${ }^{1,2}$ and Ok-Min Lee ${ }^{1, *}$ \\ ${ }^{1}$ Department of Life science, College of Natural Science, Kyonggi University, Suwon 443-760, Korea \\ ${ }^{2}$ Water Environment Research Department, National Institute of Environmental Research, Environmental Research Complex, \\ Kyungseo-dong, Seo-gu, Incheon 404-708, Korea
}

\begin{abstract}
Taxa in the order Chlorococcales inhabiting Hongcheon River, South Korea were collected and identified from December 2011 to September 2012. As a result, nine taxa in the Order Chlorococcales including unrecorded genera Oocystidium and Heleococcus were newly added to the Korean flora: Oocystidium ovale, Heleococcus mucicola, Chlorella mirabilis, Monoraphidium convolutum var. pseudosabulosum, M. minutum, Raphidocelis mucosa, Eutetramorus tetrasporus, Scenedesmus flavescens, and S. multicauda. The morphological characteristics of the nine taxa identified in this study mostly corresponded to already reported characteristics; however, M. minutum had a shorter cell length than the recorded description, Raphidocelis mucosa and S. flavescens were larger than previous descriptions, and Scenedesmus multicauda had larger spines than the cell itself. Eight of the nine taxa were found in planktonic samples, whereas Heleococcus mucicola was found in an epilithic sample. Therefore the Korean order Chlorococcales, including these newly reported ones, totals to 255 species.
\end{abstract}

Keywords: Chlorococcales, epilithic algae, Hongcheon river, new recorded species, phytoplankton

\section{INTRODUCTION}

Order Chlorococcales is taxa belong to phylum Chlorophyta and class Chlorophyceae. Chlorococcales is considered a main taxa researches about rivers, lakes, and dams (Kim and Chung 1993). These plants, along with cyanophytes and diatoms, are biological indicators of the water environment (Thunmark 1945, Reynolds 1984, Kim 1998). Chlorococcales exist as unicells or colonies with diverse sizes and shapes, and do not have flagella, eye spots, contractile vacuoles, or basal bodies (Wilcox et al. 1992).

The order Chlorococcales was classified by Pascher in 1915 based on electron microscopic microstructure and molecular biology evidence; however, due to insufficient classification standards and descriptions, the synonyms have been confused, resulting in difficulties identifying the order Chlorococcales.

The order Chlorococcales is one of the largest taxa of green algae in freshwater worldwide. Komárek and Fott (1983) recorded 15 families 248 genera and 1,025 species worldwide, whereas Hindák (1977, 1980, 1984, 1988) recorded 12 families 96 genera, and 168 species excluding the genus Scenedesmus in Western Slovakia. The Algaebase includes 20 families 109 genera, and 292 species (Guiry 2013).

In Korea, order Chlorococcales contains 246 taxa classified into 12 families, 56 genera, 181 species, 64 varieties, and 20 forms (Lee 1996). Studies including Ann and http://dx.doi.org/10.5141/ecoenv.2013.315

(C) $\$$ This is an Open Access article distributed under the terms of the Creative Commons Attribution Non-Commercial Licens (http://creativecommons.org/licenses/by-nc/3.0/) which permits unrestricted non-commercial use, distribution, and reproduction in any medium, provided the original work is properly cited.
Received 29 October 2013, Accepted 22 November 2013

*Corresponding Author

E-mail: omlee@kyonggi.ac.kr

Tel: +82-31-249-9643 


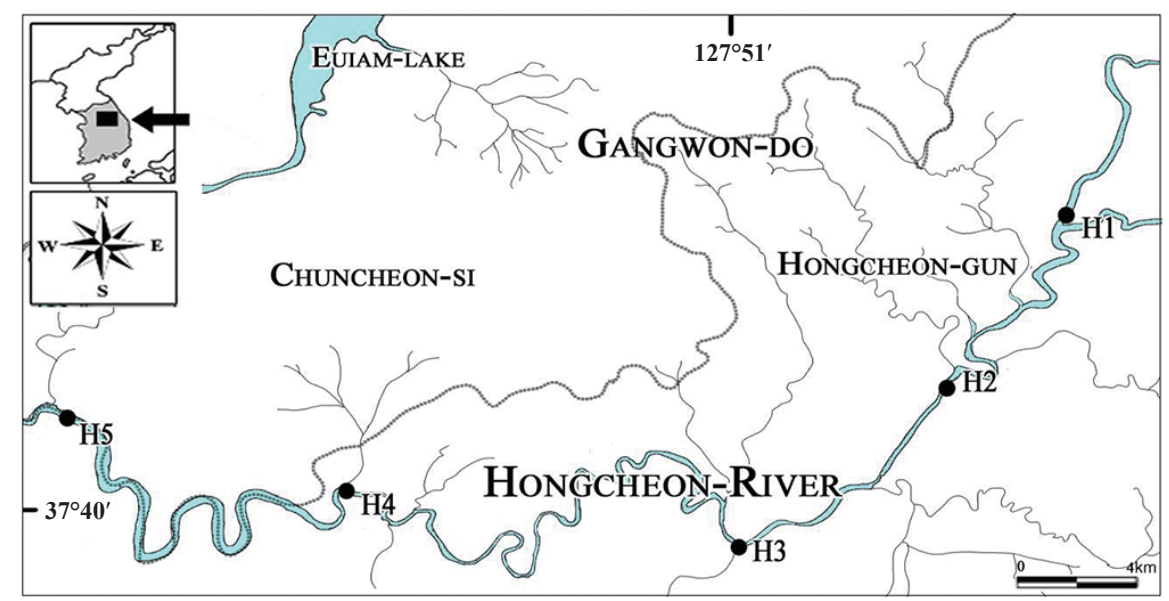

Fig. 1. Sampling sites on Hongcheon River at Gangwon-do from December 2011 to September 2012. H1, Cheoljeong-kyo; H2, Gurun-kyo; H3, Dunji-kyo; $\mathrm{H} 4$, Palbong-kyo; H5, Chungui-bridge.

Chang (1985), An and Chang (1990), Kim et al. (1991) and Kim and Chang (1997) have been conducted on the order Chlorococcales in Korea but they are far behind international studies.

In this study, we collected phytoplankton and epilithic algae in Hongcheon River, and newly recorded species to contribute the Korean flora in the order Chlorococcales.

\section{MATERIALS AND METHODS}

Order Chlorococcales specimens were collected in Hongcheon River from December 2011 to September 2012 (Fig. 1). The Hongcheon River starts in Saengok-ri Seosuk-myun Hongcheon-gun and is a second tributary of the Han River, which is $120 \mathrm{~km}$ in length (Yang et al. 1991). The vicinity of Hongcheon River is mostly mountains and farmlands, but parts go through city and factory or leisure areas (Choi and Kim 2004).

$\mathrm{H} 1$ is Cheoljeong-kyo, Cheoljeong-ri Duchon-myeon Hongcheon-gun Gangwon-do, H2 is Gurun-kyo Gurun-ri Hwachon-myeon H3 is Dunji-kyo Hahwagye-ri Bukbangmyeon, H4 is Palbong-kyo Eoyupo-ri Seo-myeon, H5 is Chungui-bridge Balsan-ri Nam-myeon Chuncheon-si (Fig, 1).

Aquatic plants, submerged land plants, and rocks were scrubbed off to collect the attached algae, and surface water was sampled with a $20 \mu \mathrm{m}$ mesh, $30 \mathrm{~cm}$ diameter phytoplankton net (Wildco, Yulee, FL, USA) to collect phytoplankton.

The collected specimens were separated by species using a Pasteur pipette under a light microscope and cul- tured in solid media. When a colony formed as a single species, it was transferred to liquid media.

All samples were examined under $\times 1000$ magnification, and pictures were taken of the cell's outer shape using an Olympus DP70 camera (Olympus, Tokyo, Japan). Then, using Adobe Photoshop CS4 (Adobe Systems, Mountain View, USA) and WACOM bamboo MTE-450K (WACOM, Seoul, Korea), the outer shapes of the cells and chlorophyll were depicted, and size is shown with a scale bar. All of specimens were deposited in the algal culture collection of Kyonggi University (ACKU) and the National Institute of Biological Resources (NIBR) in Korea.

The collected taxa were identified using the Komárek and Fott (1983) classification system, and Chung (1993), Prescott (1973), Prescott et al. (1972, 1977, 1981, 1982), Hindák (1977, 1980, 1984, 1988), Hirose et al. (1977), John et al. (2002), John and Robert (2003) were used as references. The species distribution was performed referring to Algaebase (Guiry 2013).

\section{RESULTS AND DISCUSSION}

The morphological and ecological characteristics of the nine Korean unrecorded species including the unrecorded genera Oocystidium and Heleococcus from Hongcheon River are as follows.

\section{Order Chlorococcales Family Oocystaceae Subfamily Oocystoideae Genus Oocystidium}



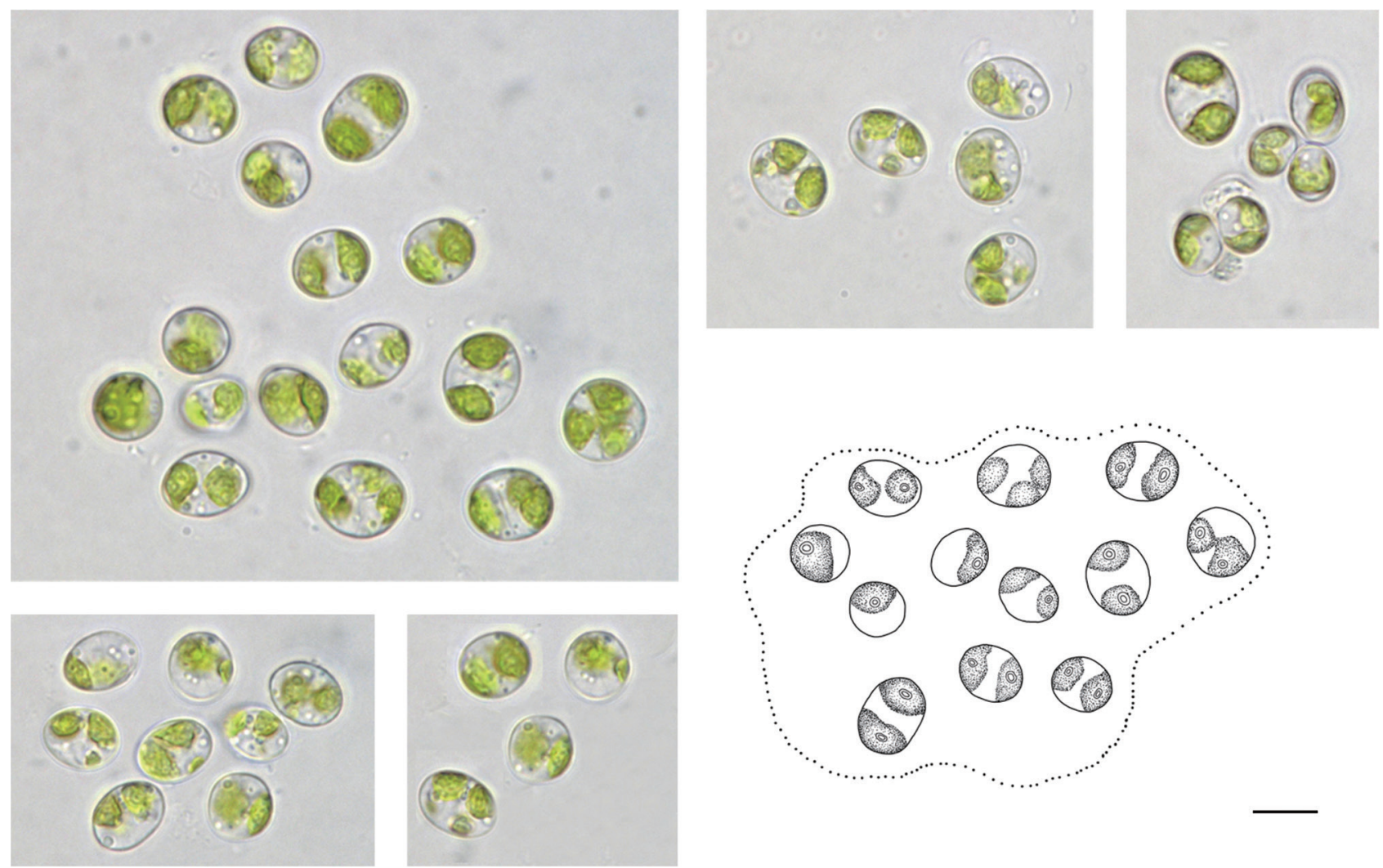

Fig. 2. Microscopic photographs and illustration of a newly recorded species, Oocystidium ovale Korshikov, in Hongcheon River of Korea from December 2011 to September 2012. Scale bar, $10 \mu \mathrm{m}$.

Genus Oocystidium was named by Korshikov in 1953. The Cell is broad oval, unicell or in 2-4 cells in mucilage. The Cell wall is smooth and thick. Chloroplasts 1-2 or parietal with pyrenoid (Komárek and Fott 1983, Guiry 2013). Three species such as O. ovale, O. ovale var. polymammilatum, and $O$. polymammilatum, have been recorded; however, only O. ovale is currently accepted (Guiry 2013).

\section{Oocystidium ovale Korshikov 1953 (Fig. 2)}

Description: Cells spherical or ellipsoidal; usually 1.3 times as long as wide, sometimes twice. Cells individually or combined into 2-4 in colonies (Komárek and Fott 1983). The apical tips of the cells have chloroplasts and are divided in two, each with a pyrenoid. Cell size is 10-19 $\mu \mathrm{m}$ long, 8-14 $\mu \mathrm{m}$ wide.

Ecology and distribution: Ponds in Romania, Spain, Argentina, Czechoslovakia, and Hungary (Komárek and Fott 1983). We found it as phytoplankton.

Site of collection: Chungui-bridge Balsan-ri Nam-myeon Chuncheon-si (H5).

Specimen: ACKU 9-296.

\section{Order Chlorococcales Family Palmellaceae Subfamily Hormotiloideae Genus Heleococcus}

Genus Hormotila was first named by Bourrelly in 1966; however, some species in this genus were transferred to Heleococcus by Korshikov in 1953. The cell combines amorphous colonies with mucilage. Sometimes layered. The cell wall is smooth and smaller vacuoles. Chloroplast single or parietal with pyrenoid (Komárek and Fott 1983, Guiry 2013). Three species have been recorded such as $H$. mucicola, $H$. polyvacuolatus, $H$. ramosissimus; however, only $H$. mucicola is currently accepted taxonomically (Guiry 2013).

\section{Heleococcus mucicola Korshikov 1953 (Fig. 3)}

Synonym: Hormotila mucicola Bourr. 1966.

Description: Cell wall is thin and smooth. Cells individual or 2-4-celled colonies with end of branch mucilage. Cells spherical or ellipsoidal. Cells $10-20 \mu \mathrm{m}$ in diameter. Chloroplast thin, parietal. The center of the cell has a vac- 

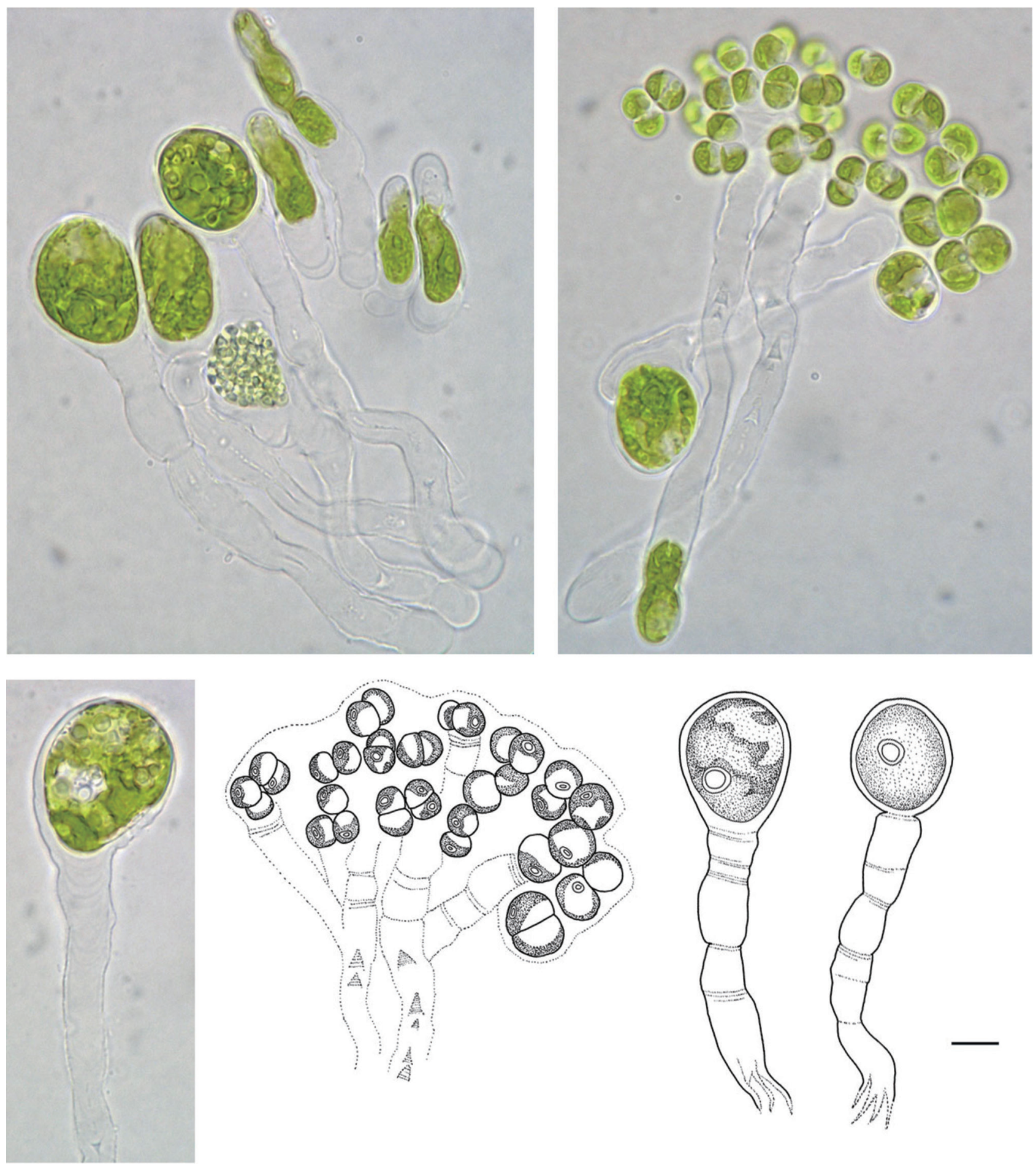

Fig. 3. Microscopic photographs and illustrations of a newly recorded species, Heleococcus mucicola Korshikov, in Hongcheon River of Korea from December 2011 to September 2012. Scale bar, $10 \mu \mathrm{m}$. 

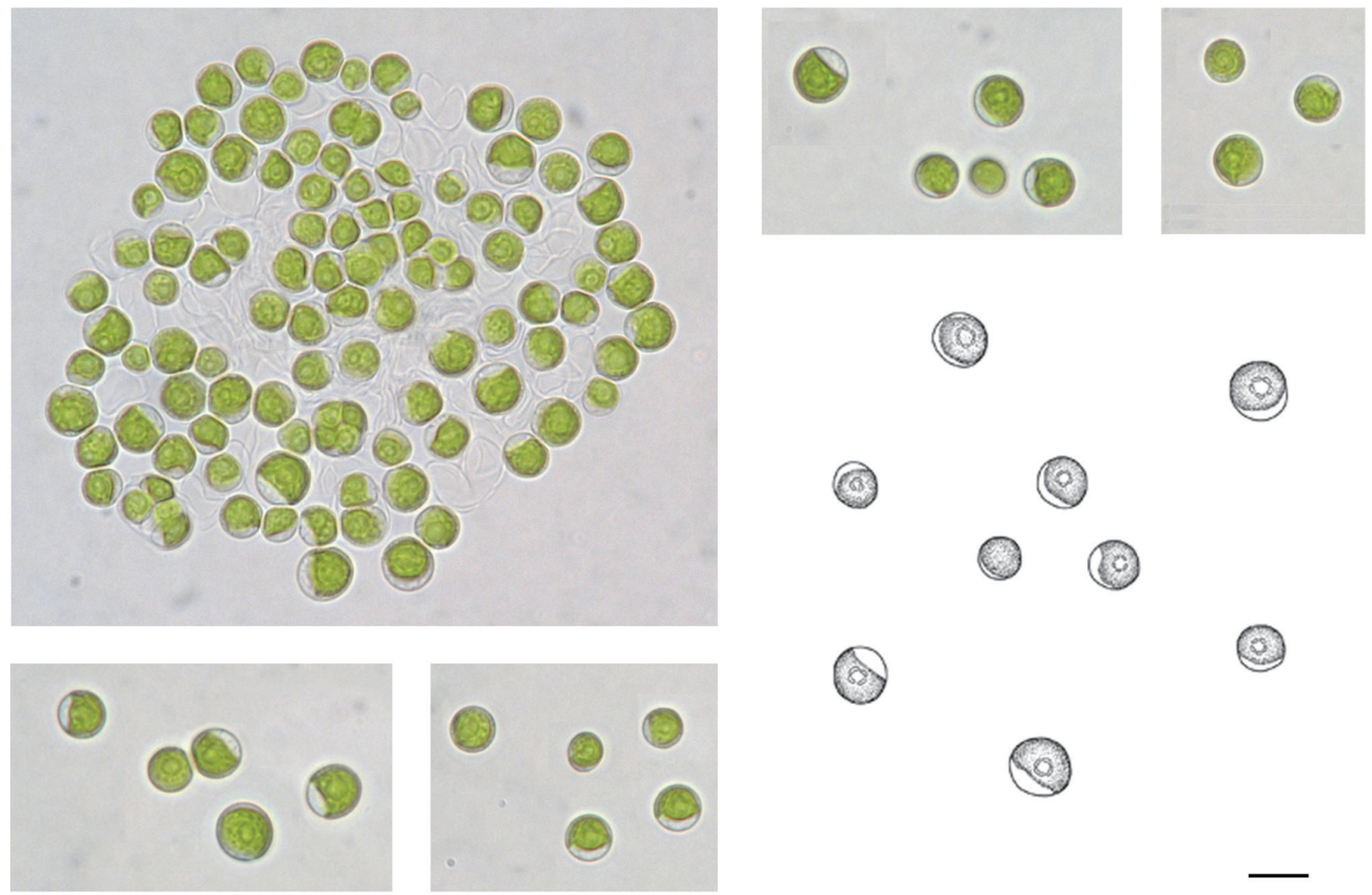

Fig. 4. Microscopic photographs and illustration of newly recorded species, Chlorella mirabilis V. M. Andreeva, in Hongcheon River of Korea from December 2011 to September 2012. Scale bar, $10 \mu \mathrm{m}$.

uole (Komárek and Fott 1983).

Ecology and distribution: Ireland and Sweden in overgrown swamps and sphagnum ponds (Komárek and Fott 1983). We found this species as epilithic algae in a river.

Site of collection: Dunji-kyo Hahwagye-ri Bukbangmyeon (H3).

Specimen: NIBRCL0000104603, ACKU 9-302.

\section{Order Chlorococcales Family Chlorellaceae Subfamily Chlorelloideae}

\section{Chlorella mirabilis V. M. Andreyeva 1975 (Fig. 4)}

Description: Cells individual, most spherical; young cells spherical and slight ellipsoidal. Cells $2-8 \mu \mathrm{m}$ in diameter. Chloroplast parietal, usually filling two-thirds of the cell. Pyrenoid has small fragment.

Ecology and distribution: The Black Sea, Russia and at the bottoms of rivers in the tundra (Komárek and Fott 1983). It is also found in terrestrial habitats (Guiry 2013). We found it as phytoplankton.

Site of collection: Dunji-kyo Hahwagye-ri Bukbang- myeon (H3).

Specimen: ACKU 9-301.

\section{Order Chlorococcales Family Chlorellaceae Subfamily Ankistrodesmoideae}

\section{Monoraphidium convolutum var. pseudosabulosum}

Hindák 1970 (Fig. 5)

Description: Cells individual or in a colony, Cell size is 4-6 $\mu \mathrm{m}$ wide, 12-16 $\mu \mathrm{m}$ long. Cells irregular or crescent; side of cell is convex and other side of cell is concave or spindle shape. Cell is blunt rather than acuminated, often associated with the end (Komárek and Fott 1983).

Ecology and distribution: Eutrophic water in Britain and the Hawaiian Islands, scattered as plankton and metaphyton mesotrophic, but widespread, probably cosmopolitan (Komárek and Fott 1983).

Site of collection: Gurun-kyo Gurun-ri Hwachon-myeon (H2).

Specimen: NIBRCL0000104605, ACKU 9-299. 

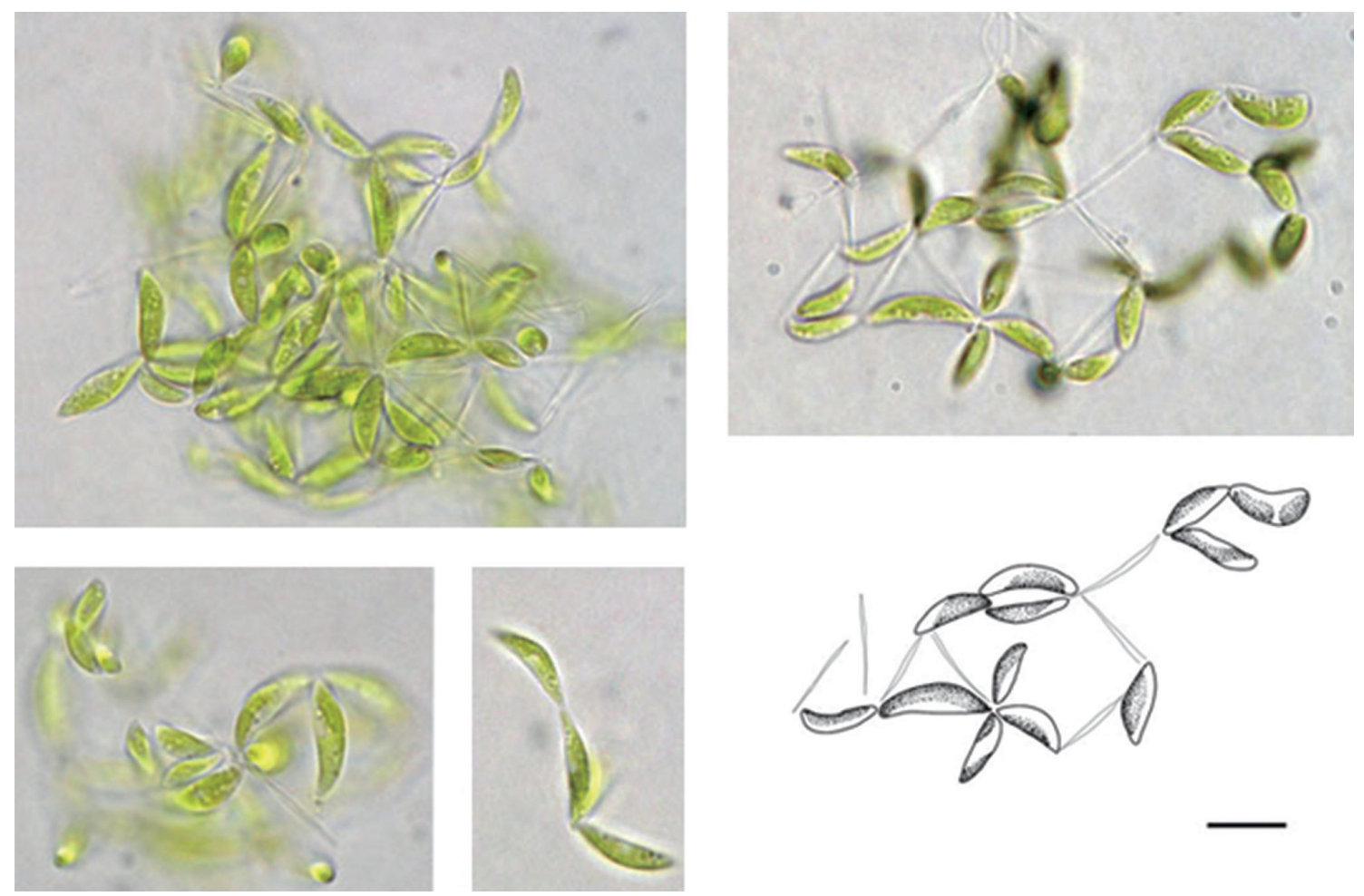

Fig. 5. Microscopic photographs and illustration of a newly recorded species, Monoraphidium convolutum var. pseudosabulosum Hindák, in Hongcheon River of Korea from December 2011 to September 2012. Scale bar, $10 \mu \mathrm{m}$.
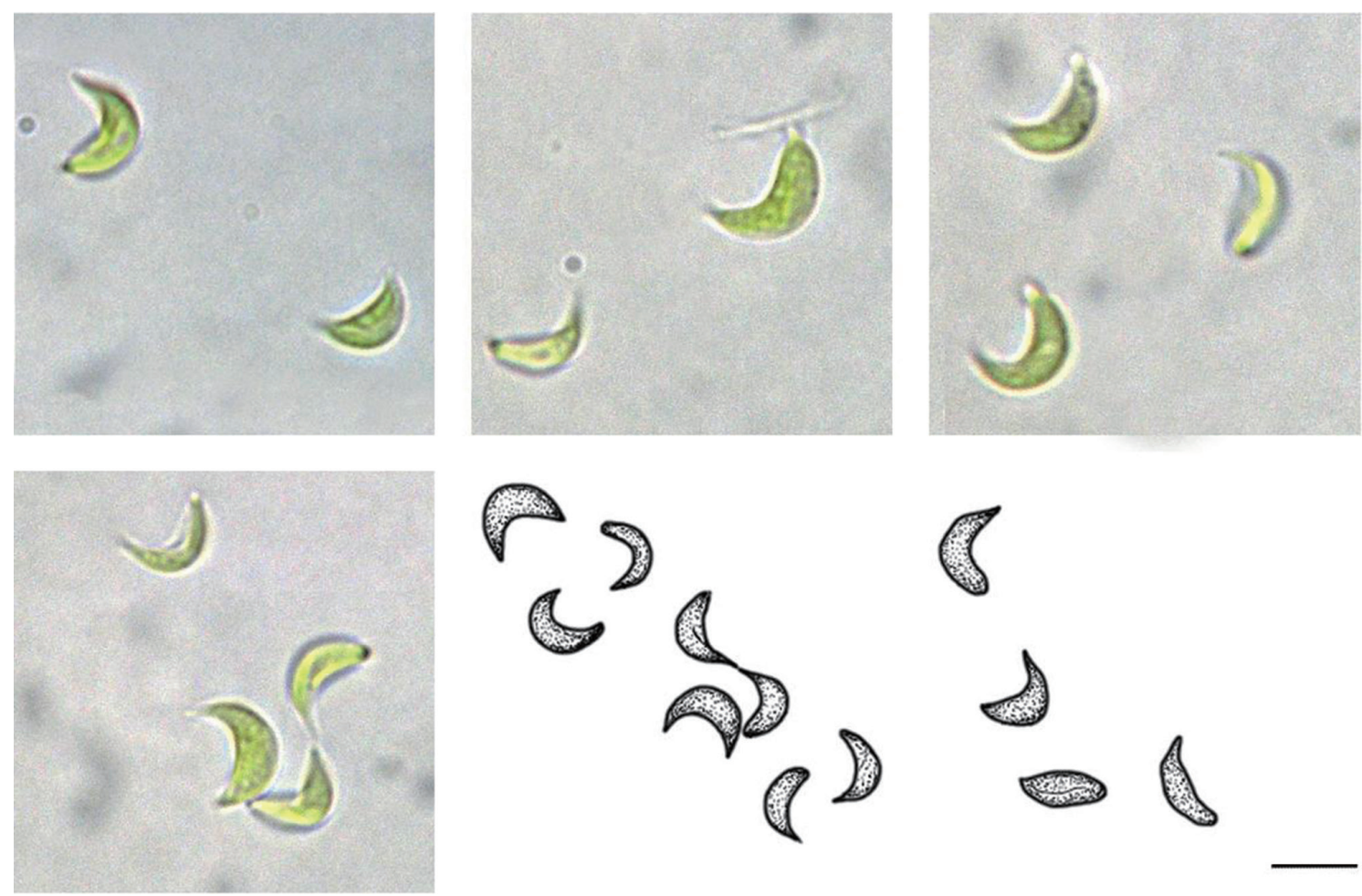

Fig. 6. Microscopic photographs and illustrations of newly recorded species, Monoraphidium minutum Komárková-Legnerová, in Hongcheon River of Korea from December 2011 to September 2012. Scale bar, $10 \mu \mathrm{m}$. 

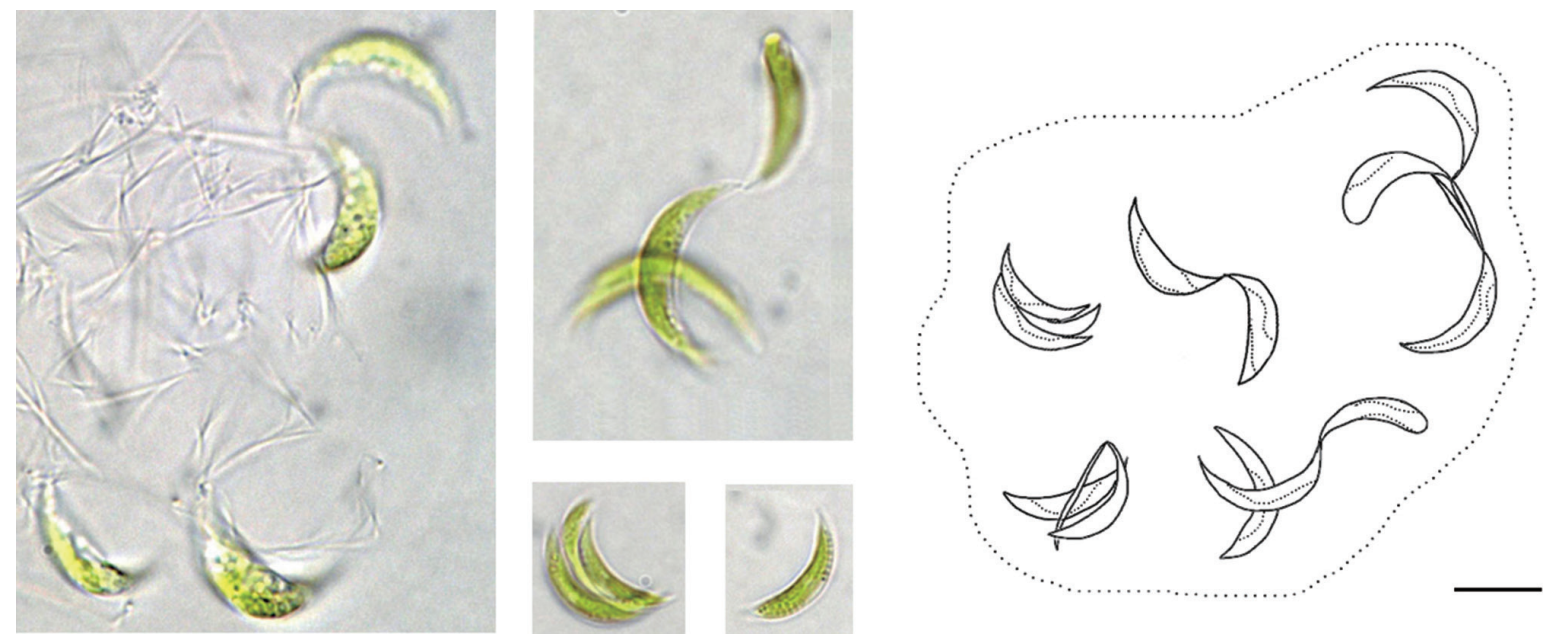

Fig. 7. Microscopic photographs and illustration of newly recorded species, Raphidocelis mucosa Komárek, in Hongcheon River of Korea from December 2011 to September 2012. Scale bar, $10 \mu \mathrm{m}$.

\section{Order Chlorococcales Family Chlorellaceae \\ Subfamily Ankistrodesmoideae}

Monoraphidium minutum Komárková-Legnerová 1969 (Fig. 6)

Synonyms: Raphidium minutum Nág. 1849, Selenastrum minutum Collins 1907, Ankistrodemus convolutes var. obtusus Printz 1916, A. minutissimus Kors 1953, and A. lunulatus Belcher \& Swale 1962.

Description: Cells very small and individually crescent shaped, end part of cell is spiral. Chloroplast parietal, filling most of the cell, without a pyrenoid. Cells connected with a cell wall (Komárek and Fott 1983). Cell size is 1-3 $\mu \mathrm{m}$ wide, $3-10 \mu \mathrm{m}$ long.

This species is smaller than the recorded description (3.5-20 $\mu \mathrm{m}$ long) by Komárková and Legnerová (1969).

Ecology and distribution: Ontario, China, and New South Wales, scattered in plankton and metaphyton in mesotrophic water; probably cosmopolitan but more in tropical and subtropical waters (Komárek and Fott 1983).

Site of collection: Gurun-kyo Gurun-ri Hwachon-myeon (H2).

Specimen: ACKU 9-300.

\section{Order Chlorococcales Family Chlorellaceae Subfamily Ankistrodesmoideae}

\section{Raphidocelis mucosa Komárek 1979 (Fig. 7)}

Synonyms: Ankistrodesmus mucosus Korschikov 1953,
Kirchneriella mucosa Hind 1977.

Description: Cells individual or in colonies, with irregular arrangement of cells in mucilage. Cells narrowly fusiform, straight or slightly curved; crescent shape at a blunt end. Chloroplast parietal without a pyrenoid. Cells size is $2-5 \mu \mathrm{m}$ wide, $4-12 \mu \mathrm{m}$ long.

This species was wider than the recorded description (1.5-2.5 $\mu \mathrm{m}$ wide) by Komárková (1979).

Ecology and distribution: Planktonic in Romania; however, it has been specified up to now only in Czechoslovakia and Russia (Komárek and Fott 1983).

Site of collection: Palbong-kyo Eoyupo-ri Seo-myeon (H4).

Specimen: ACKU 9-298.

\section{Order Chlorococcales Family Radiococcaceae Subfamily Radiococcoideae}

\section{Eutetramorus tetrasporus Komárek 1983 (Fig. 8)}

Description: Cell size is $3-5 \mu \mathrm{m}$ in diameter. Colonies 4 , 8, or 16-celled but mostly four-celled (Komárek and Fott 1983), Cells spherical, early young cells are triangular in shape with mother cell in mucilage. Mature cells mostly spherical. Chloroplast parietal, each with a pyrenoid.

Ecology and distribution: Romania, Brazil, and Cuba in eutrophic water as plankton (Komárek and Fott 1983).

Site of collection: Gurun-kyo Gurun-ri Hwachon-myeon (H2).

Specimen: ACKU 9-297. 

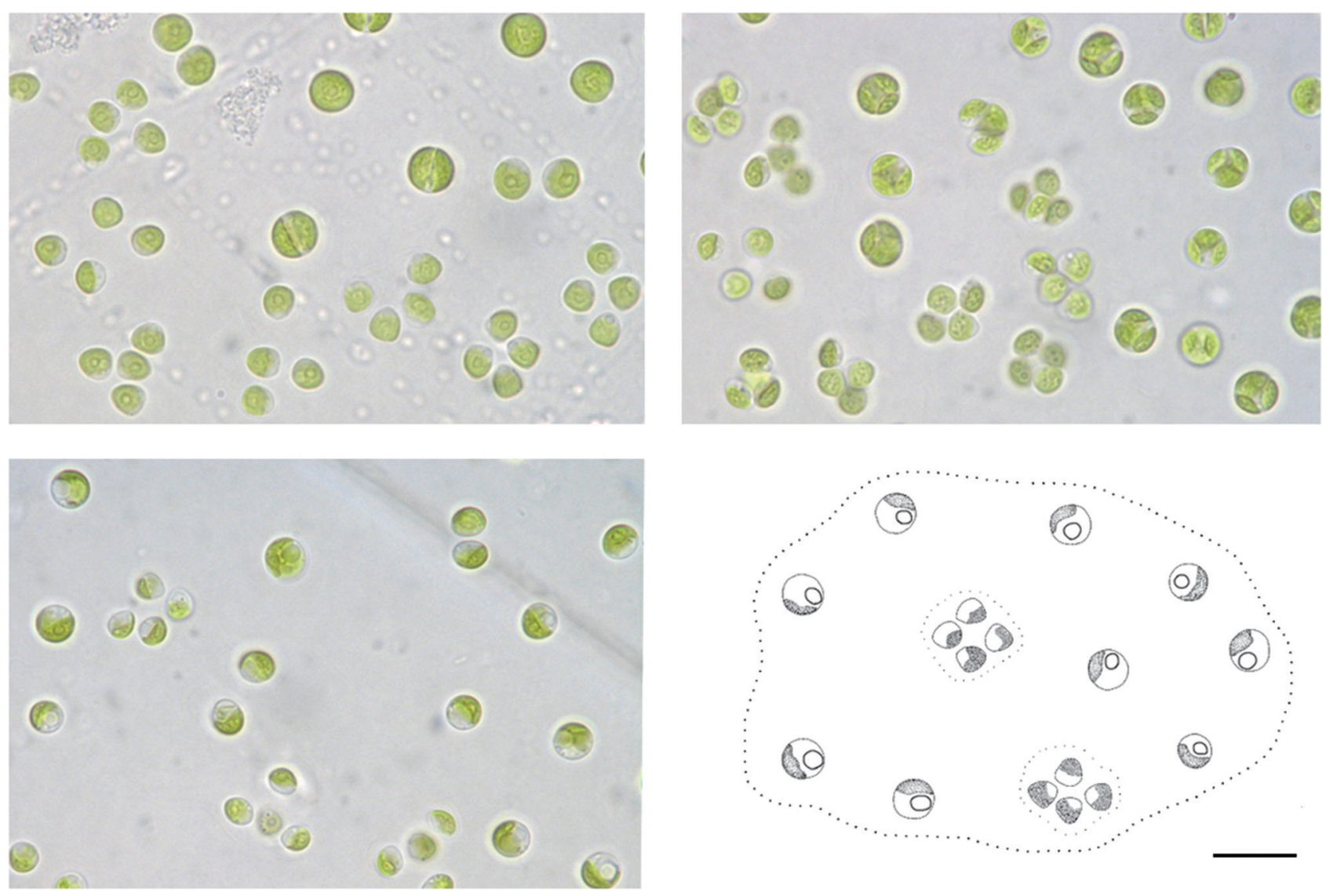

Fig. 8. Microscopic photographs and Illustration of newly recorded species, Eutetramorus tetrasporus Komárek in Hongcheon River of Korea from December 2011 to September 2012. Scale bar, $10 \mu \mathrm{m}$.

\section{Order Chlorococcales Family Scenedesmaceae Subfamily Desmodesmoideae}

\section{Scenedesmus flavescens Chodat 1913 (Fig. 9)}

Description: Colonies 2, 4, or 8-celled, most are 4-celled colonies. Outer cell is ellipsoidal, spindle shape, the lateral margins are swollen. Inner cell is elongated oval, spindle shape sometimes rounded and pentagon shaped. Both ends of the outer cell have two spines with a variety of sizes (long and short); center of outer cells has 1-2 short spine. Both ends of the inner cells have 1-2 short spines. Cell size is $8-10 \mu \mathrm{m}$ wide, $18-30 \mu \mathrm{m}$ long.

This species was larger than the recorded description (1.7-7 $\mu \mathrm{m}$ wide, 5.5-15 $\mu \mathrm{m}$ long) by Chodat (1913).

Ecology and distribution: Britain and Portugal and is planktonic in rivers.

Site of collection: Palbong-kyo Eoyupo-ri Seo-myeon (H4).

Specimen: NIBRCL0000104608, ACKU 7-257.

\section{Order Chlorococcales}

Family Scenedesmaceae

Subfamily Scenedesmoideae

\section{Scenedesmus multicauda Masyuk 1962 (Fig. 10)}

Description: Cells ellipsoidal, linear, slightly curved toward the outside. Four-celled colonies, sometimes found as two-celled colonies (Komárek and Fott 1983). Both inner and outer cells outside are long; 1-2 spines at the poles. Cell size is $3-10 \mu \mathrm{m}$ wide, $7-13 \mu \mathrm{m}$ long.

Masyuk (1962) described the spines as long or slightly shorter yet similar, but this species has longer spines than the cell size.

Ecology: Ponds and lakes as phytoplankton (Komárek and Fott 1983).

Site of collection: Cheoljeong-kyo Cheoljeong-ri Duch on-myeon (H1).

Specimen: NIBRCL0000104609, ACKU 7-258.

The morphological characteristics of the nine taxa 

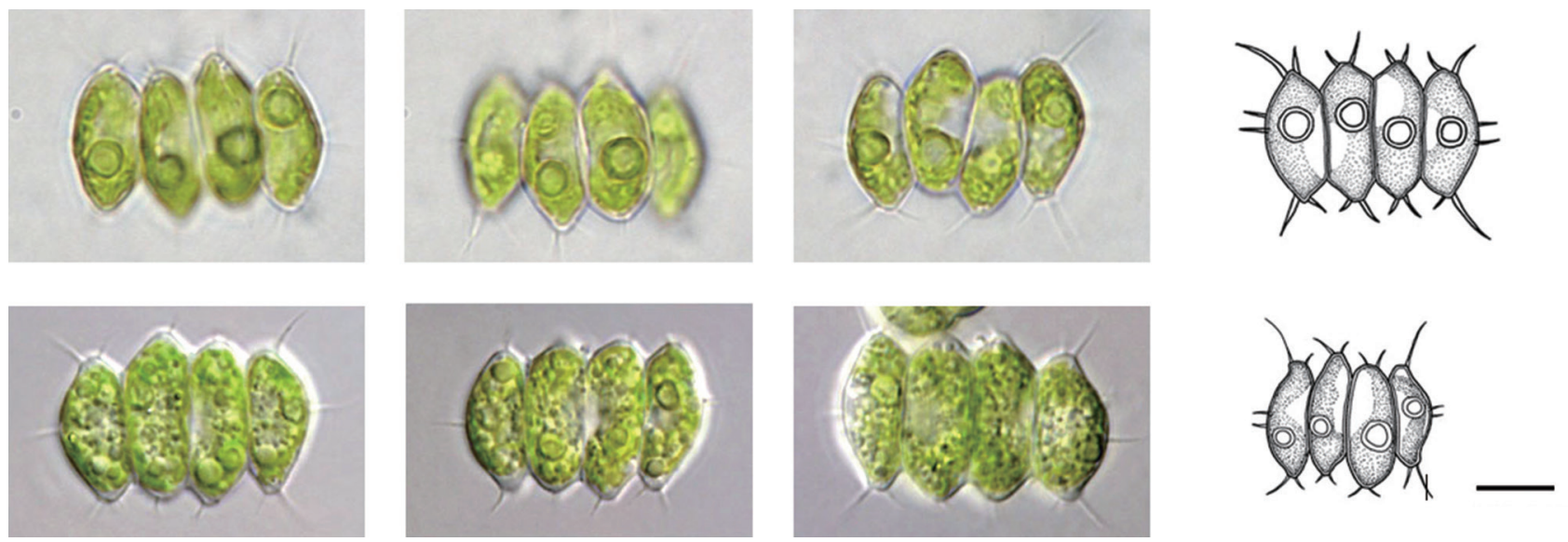

Fig. 9. Microscopic photographs and illustrations of newly recorded species, Scenedesmus flavescens Chodat, in Hongcheon River of Korea from December 2011 to September 2012. Scale bar, $10 \mu \mathrm{m}$.
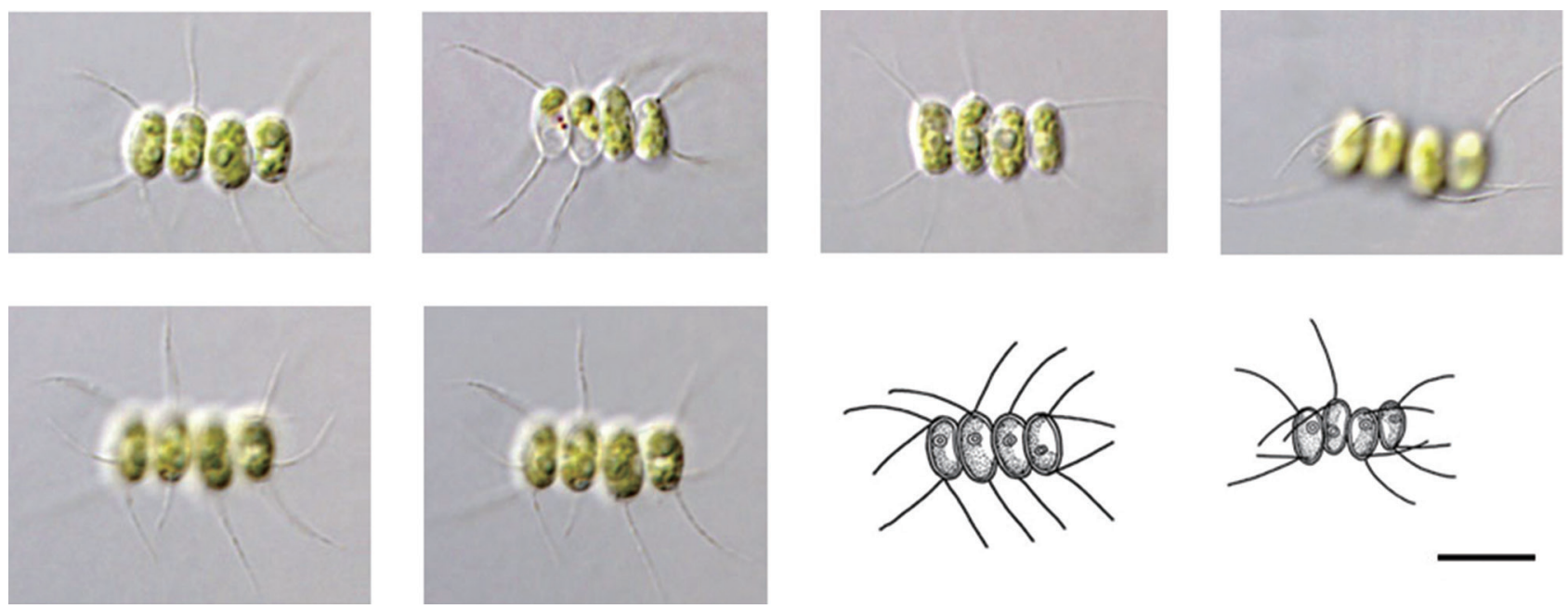

Fig. 10. Microscopic photographs and illustrations of newly recorded species, Scenedesmus multicauda Masyuk, in Hongcheon River of Korea from December 2011 to September 2012. Scale bar, $10 \mu \mathrm{m}$.

identified in this study mostly corresponded to the reported characteristics; however, Monoraphidium minutum had a shorter cell length than the recorded description and Raphidocelis mucosa and S. flavescens were larger than their previous descriptions. S. multicauda had larger spines than the cell itself.

Eutetramorus planctonicus and E. polycoccus were transferred to genus Coenococcus by Komárek and Fott due to a lack of taxonomic characters; however, E. tetrasporus is considered a species.

The genus Scenedesmus was named by Meyen in 1829 and was classified into four subgenera in 1926 by Cho- dat (Clathrodesmus, Desmodesmus, Euscenedesmus and Rhynchodesmus). However, a recent taxonomic evaluation by Trainor et al.(1976) has divided it into the spiny genus Desmodesmus and the non-spiny genus Scenedesmus (Lürling 2003). S. flavescens and S. multicauda are also considered as genus Desmodesmus according to Trainor et al. (1976).

The reported number of Korean species in the order Chlorococcales flora is very low compared to the internationally reported taxa. Therefore, more studies in various habitats are needed. 


\section{ACKNOWLEDGMENTS}

This work was supported by a grant from the National Institute of Biological Resources (NIBR), as funded by the Ministry of Environment (MOE) of the Republic of Korea (NIBR No. 2013-01-001).

\section{LITERATURE CITED}

An SS, Chang YK. 1990. A taxonomic study on the genus Scenedesmus in Korea (1). Algae 5: 123-129.

Andreyeva VM. 1975. Novye vidy Chlorella Beijer [New species of the Chlorella Beijer]. Bot Zhurn (St. Petersburg) 58: 1735 .

Ann SS, Jang YK. 1985. Morphological variation of Scenedesmus quadricauda (Turpin) de Brebisson and Scenedesmus armatu (Chodat) G. M. Smith in culture. Kor J Bot 28: 305-315.

Bourrelly P. 1966. Quelques algues d'eau douce du Canada. Int. Rev ges Hydrobiol 51: 45-126.

Chodat R. 1913. Monographies d'algues en culture pure. Materiaux pour la flore cryptogamique Suisse. Vol 5, Fasc K J. Wyss, Berne, pp 2.

Chodat R. 1926. Scenedesmus Etude de génétique, de systématique expérimentale et d'hydrobiologie. Rev Hydrobiol 3: 71-258.

Choi JS, Kim JK. 2004. Ichthyofuna and fish community in Hongcheon river, Korea. Kor J Environ Biol 18: 446-455.

Chung J. 1993. Illustration of the freshwater algae of Korea. Academy Publishing co., Seoul.

Guiry MD. 2013. Algaebase. http://www.algaebase.org/. Accessed 27 June 2013.

Hindák F. 1970. A contribution to the systematics of the family Ankistrodesmaceae (Chlorophyceae). Algol Stud 1: 7-32.

Hindák F. 1977. Studies on the chlorococcal algae (Chlorophyceae). Vol I. Biologické práce 23. VEDA Publishing House Slovak Academy of Sciences, Bratislava.

Hindák F. 1980. Studies on the chlorococcal algae (Chlorophyceae). Vol II. Biologické práce 26. VEDA Publishing House Slovak Academy of Sciences, Bratislava.

Hindák F. 1984. Studies on the chlorococcal algae (Chlorophyceae). Vol III. Biologické práce 30. VEDA Publishing House Slovak Academy of Sciences, Bratislava.

Hindák F. 1988. Studies on the chlorococcal algae (Chlorophyceae). Vol IV. Biologické práce 34. VEDA Publishing House Slovak Academy of Sciences, Bratislava.

Hirose HM, Akiyama T, Imahori K, Kasaki H, Kumano S, Kobayasi H, Takahashi E, Tsumura T, Hirano M, Yamagishi
T. 1977. Illustrations of the Japanese freshwater algae. Uchidarokakuho Publ Co., Ltd., Tokyo.

John DM, Whitton BA, Brook AJ. 2002. The freshwater algal flora of the British Isles: An Identification guide to freshwater and terrestrial algae. Cambridge University Press, Cambridge.

John DW, Robert GS. 2003. Freshwater algae of North America: Ecology and Classification. 1st ed. Academic Press, San Diego, CA.

Kim HS, Chung J. 1993. Freshwater algal flora of natural swamps in Changnyong County. Korean J Limnol 26: 305-319.

Kim MR, An SS, Chang YK. 1991. Morphological variations of Scenedesmus quadricauda var. biornatus Kiss. Korean J Limnol 24: 109-116.

Kim MR, Chang YK. 1997. Taxonomic studies on some species of Pediastrum Meyen in Korea. Algae 12: 159-165.

Kim YJ. 1998. Ecological characteristics of phytoplankton community in lake Paltang Dam. Korean J Limnol 31: 225-234.

Komárek J. 1979. Änderungen in der taxonomie der chlorokokkalalgen. Archiv Hydrobiol Suppl 56 (Algological Studies) 24: 239-263.

Komárek J. 1983. Contribution to the chlorococcal algae of Cuba. Nova Hedwigia 37: 65-180.

Komárek J, Fott B. 1983. Chlorophyceae (Grunalgen) ordnung: Chlorococcales. In: Das phytoplankton des susswassers, 7 Teil, 1 Halfte (Thienemann A, ed). E Schweizerbart'sche Verlagsbuchhandlung (Nägele $u$. Obermiller), Stuttgart.

Komárková - Legnerová, J. 1969. The systematics and ontogenesis of the genera Ankistrodesmus Corda and Monoraphidium gen. nov. In: Studies in Phycology (Fott B, ed). E Schweizerbart'sche Verlagsbuchhandlung (Nägele u. Obermiller), Stuttgart, pp 75-144.

Korshikov O. 1953. The Freshwater algae of the Ukrainian SSR. V. Sub-Class Protococcineae. Vacuolales and Protococcales. Akad Nauk URSR, Kiev.

Lee OM. 1996. Freshwater chlorophyta. In: Species List in Korea (Lee IK, ed). The Korean National Council for Conservation of Nature, Seoul, pp 405-422. (in Korean)

Lürling M. 2003. Phenotypic plasticity in the green algae Desmodesmus and Scenedesmus with special reference to the induction of defensive morphology. Ann Limnol Int J Lim 39: 85-101.

Masyuk NP. 1962. New and interesting species of the genus Scenedesmus MEYEN from basins of the Volynian forest zone. U krain Bot Žhurn 19: 73-83.

Meyen FJF. 1829. Beobachtungen über einige niedere Algenformen. Nova Acta Physico-Medica Academiae Cae- 
sareae Leopoldino-Carolinae Naturae 14: 768-778.

Pascher A. 1915. Die Süsswasser-Flora Deutschlands, Österreichs und der Schweiz. Heft 5. Chlorophyceae II. Jena: Gustav Fischer.

Prescott GW, Bicudo CEM, Vinyard WC. 1982. A synopsis of North American Desmids. Part II. Section 4. The University of Nebraska Press, Lincoln, NE.

Prescott GW, Croasdale HT, Vinyard WC. 1972. North American flora, Series II. Part 6. Desmidiales. New York Botanical Garden, New York.

Prescott GW, Croasdale HT, Vinyard WC. 1977. A synopsis of North American Desmids. Part II. Desmidiaceae: Placodermae. Section 2. The University of Nebraska Press, Lincoln, NE.

Prescott GW, Croasdale HT, Vinyard WC, Bicudo CEM. 1981. A synopsis of North American Desmids. Part II, Section 3. The University of Nebraska Press, Lincoln, NE.

Prescott GW. 1973. Algae of the western great lakes area. Otto
Koeltz Science Publishers, Koenigstein

Reynolds CS. 1984. Phytoplankton periodicity: the interaction of form, function and environmental variability. Freshw Biol 14: 111-142.

Thunmark S. 1945. Zur soziologie des subwasser planktons. Fine methodologisch- okologische Studie. Folia Limnol Scand 3: 1-6.

Trainor FR, Cain JR, Shubert EL. 1976. Morphology and nutrition of the colonial green alga Scenedesmus : 80 years later. Bot Rev 42: 5-25.

Wilcox LW, Lewis LA, Fuerst PA, Floyd GL. 1992. Assessing the relationships of autosporic and zoosporic chlorococcalean green algae with 18 S rDNA sequence data. J Phycol 28: 381-386.

Yang HJ, Chae BS, Nam MM. 1991. The ichthyofauna in autumn at upper reach of Hongchon River. Korean J Limnol 24: 37-44. 